\title{
ATP1A1 wt Allele
}

National Cancer Institute

\section{Source}

National Cancer Institute. ATP1A1 wt Allele. NCI Thesaurus. Code C113763.

Human ATP1A1 wild-type allele is located in the vicinity of 1 p21 and is approximately 38 $\mathrm{kb}$ in length. This allele, which encodes sodium/potassium-transporting AT Pase subunit alpha-1 protein, plays a role in both ATP metabolism and cation transport. 